\title{
Impact of agro-climatic conditions of Faisalabad on growth performance of Portulaca genotypes
}

\author{
Muhammad Farhan Khan Pasha ${ }^{1 *}$, Summaira Ali ${ }^{2}$ and Abrar Ahmed ${ }^{3}$ \\ 1. Institute of Horticultural Sciences, University of Agriculture, Faisalabad-Pakistan \\ 2. Pir Maher Ali Shah-Arid Agriculture University Rawalpindi-Pakistan \\ 3. The University of Agriculture, Peshawar-Pakistan \\ *Corresponding author's email: farhan_khan9972@yahoo.com
}

Citation

Muhammad Farhan Khan Pasha, Summaira Ali and Abrar Ahmed. Impact of agro-climatic conditions of Faisalabad on growth performance of Portulaca genotypes. Pure and Applied Biology. Vol. 10, Issue 3, pp770-780. http://dx.doi.org/10.19045/bspab.2021.100079

\begin{tabular}{llll}
\hline \hline Received: 01/09/2020 & Revised: 20/11/2020 & Accepted: 24/11/2020 & Online First: 05/12/2020 \\
\hline \hline
\end{tabular}

\section{Abstract}

Portulaca oleracea $L$. is a warm-climate, herbaceous succulent annual plant with a cosmopolitan distribution belonging to the Portulacaceae family. The majority of Portulaca genotypes are succulents that do well in drought and desert gardens. This characteristic of Portulaca genotypes formulates them as the main candidate for gardens and landscape in the region with water scarcity and saline soils. The selection of exotic genotypes in the novel atmosphere is not an easy task. Present research was designed to evaluate the growth performance of various Portulaca grandiflora genotypes. The variability among the Partulaca genotypes was observed to find out the best performer under the agro-climatic conditions of Faisalabad, Pakistan. Five Portulaca grandiflora genotypes were grown in the Institute of Horticultural Sciences' research field, University of Agriculture Faisalabad, and data was recorded for morphological traits. The conducted experiment was laid out in Randomized Complete Block Design with three replications. The data on eight morphological traits i.e. height of the plant, number of shoots, shoot length, number of leaves per branch, number of leaves on the plant, number of days to flower emergence, and flower size were recorded and analyzed. Amongst the five genotypes, significant variation was seen for different yield and growth-related parameters. Main parameters that were analyzed during the study include the height of the plant, number of shoots, shoot length, number of leaves per branch, number of leaves on the plant, number of days to flower emergence and flower size Out results suggested that "Portulaca long time bloom" performed best in vegetative and flowering traits followed by "Portulaca Yubi Pink" in agro-climatic conditions of Faisalabad.

Keywords: agro-climatic conditions; morphological traits; performance evaluation; Portulaca genotypes

\section{Introduction}

Portulaca grandiflora is known by several different names like sun plant, rose moss, moss rose as well as portulaca. It is extensively cultivated in tropical and subtropical regions. It grows well in sunny, dry locations and rock gardens. It is grown as an edging plant and intercropping in bulk 
on beds. It belongs to the family Portulacaceae, order Caryophyllales. Based on life span, it is grouped into two types, annual and perennial. Portulaca has up to 100 plant species. Warm tropical flowers are appearing in temperate climates. The annual $P$. grandiflora, a succulent herb, has many single and double-flowered varieties in various colors. The perennial type of Potulaca is a hardy herbaceous plant that produces only double flowered varieties and is likely to have limited color shade compared to the annual. Portulaca flower is ephemeral and open almost simultaneously early morning. However the time of flower wilting is significantly affected by weather conditions. Flowers often wilt during the dry and hot days whereas most do not wilt until evening [1]. Purslane is a quite common Portulaca and is an integral member of the Portulacaceae family. It is pervasive as a wild plant and had been ranked at $8^{\text {th }}$ position nearly all common flora on the earth [2]. Portulaca flowers have many different styles and textures, but the majority of varieties are succulents (fleshy plants with their own water storage for dry conditions) that do well in drought-tolerant and desert gardening. Portulaca grows eagerly in media that could be dry and salty. Consequently, it is planned as halophyte in the Halophyte database. [3] Taking into accounts its forbearance particularly to the chlorine saline condition Portulaca is recommended as a capable aspirant for use of sewerage water reutilization scheme. Portulaca is not merely important for its survival tendency and low water consumption but on the other hand also important for its utility as a vegetable and oil extraction crop. The exceptional nutritive eminence of portulaca and its excellent forbearance towards $\mathrm{Cl}$ salinity give this class a capable halophyte candidate for saline gardening. Nevertheless, be short of scientific studies on the biological, physiological, and biochemical mechanisms reinforcing it as salt tolerant, another scientific research elaborated the reticence effects of salinity on sapling growth of Portulaca [4].

Introduction of foreign cultivars in new agro-climate is difficult as their performance is affected by prevailing climatic factors. The quality production of Portulaca could be achieved by using of suitable environmental conditions, which are desired by the plant. The development of cultivars or varieties, which can be adapted to a wide range of diversified environments, is the ultimate goal of plant breeders in crop improvement programs. The adaptability of a variety over diverse environments is usually tested by the degree of its interactions with different environments under which cultivar is planted. A genotype is measured as adapted or established if that genotype has a high average yield. Less degree of stability is observed in cultivars' yielding aptitude when cultivars are raised in different environmental conditions. Zinnia elegans had a prominent effect on its growth and flowering traits under other climatic conditions [5]. It is commonly observed that at any place where environment is hot and arid, Portulaca is planted for its vibrant and colorful flowers. Portulaca is also used for plantation in rock landscape, in masses and as ground cover.

The research proposed in this manuscript provides a simplest solution that well adopted and efficient genotype can perfume better with nominal applications of fertilizer and pesticide. Considering the socioeconomic condition of Country, small scale floriculture industries with minimal inputs in agricultural domain can be benefited from this cost effective simple genotype evaluation and selection. Various genotype of Portulaca in varied climatic situation performed in an unlike way. Portulaca genotype has high temperature requisite and 
high temperature is a trait of Faisalabad climate. Therefore this research was designed for the assessment of Portulaca genotypes for variability regarding the growth and flowering indices. Variability and performance of available genotypes of Portulaca was studied to identify the best performing genotype in local climate conditions of Faisalabad, Pakistan.

\section{Materials and Methods}

Site of the experiment

The current research trial was carried out in Pakistan, University of Agriculture Faisalabad, Institute of Horticultural
Sciences, Horticulture Research Area during spring 2018.

Geography and meteorology of site

Faisalabad is situated in the slight slopes and even plains north-east of Punjab and sandwiched between longitude $73^{\circ}-6^{\prime}$ East, latitude $31^{\mathrm{O}}-26^{\prime}$ North, at an altitude of $184 \mathrm{~m}$ (604 ft.) above ocean level. Weather data presented in (Table 1) was collected and composed by Agricultural Meteorology Cell, Crop Physiology Department, University of Agriculture Faisalabad.

Table 1. Weather conditions

\begin{tabular}{|c|c|c|c|c|c|c|}
\hline \multirow{2}{*}{ Month } & \multicolumn{3}{|c|}{ Temperature } & \multirow{2}{*}{ Moisture } & \multirow{2}{*}{ Precipitation } & \multirow{2}{*}{ Day length } \\
\cline { 2 - 4 } & Max & Min. & Avg. & & mm & Hours \\
\hline & ${ }^{\circ} \mathrm{C}$ & ${ }^{\circ} \mathrm{C}$ & ${ }^{\circ} \mathrm{C}$ & $\%$ & 6.8 & 8.43 \\
\hline March & 26.37 & 13.15 & 19.76 & 59.84 & 20.9 & 9.337 \\
\hline April & 32.02 & 17.22 & 24.84 & 46.95 & 14.6 & 10.4 \\
\hline May & 40.65 & 24.855 & 32.75 & 42.98 & 78.3 & 9.38 \\
\hline June & 38.57 & 26.017 & 32.29 & 54.95 & & \\
\hline
\end{tabular}

\section{Plant material}

Seed was obtained by a limited seed business company Chanan Din Lahore. Seeds of all genotype were sown discretely in pots for nursery growing and after that were shifted to the $12^{\prime \prime}$ pots each comprising one plant in each pot. Seeds were sown on the $18^{\text {th }}$ of March, 2018, in the afternoon. It took about 4 days to germinate and they were transplanted after 26 days. The well-rotted leaf compost was used only on time of pot filling. No chemical fertilizer or chemical treatment was used.

\section{Genotypes}

Genotypes used were Portulaca long time blooming, Portulaca F-1 Sundial peach, Portulaca extra double large-flowered, Portulaca Sunnyboy Flame, and Portulaca Yubi Pink.

\section{Treatments}

Homogeneous horticultural practices were applied to all the saplings under research. Throughout the tenure of the trial, all further cultural practices like weeding, sapling protection procedures, earthen up, staking, etc. were kept alike for every entry. Five different cultivars were used with three replications.

\section{Growth indices}

Following morphological characters were observed during the study like germination \%age, number of leaves per branch, number of leaves per plant, leaf length $(\mathrm{cm})$, number of shoots, number of flowers per plant and flower diameter.

\section{Statistical analysis}

Data were subject to statistical analysis for significant differences by means of analysis of variance technique [6]. Evaluation of means was interpreted according to LSD Test at $5 \%$ level of significance.

\section{Results and Discussion}

The quality production of Portulaca plants can be achieved by using suitable genotype under favorable environmental conditions. To attain this objective, different genotype 
were grown and some important morphological traits were studied to conclude the performance of Portulaca genotype under the agro-climatic conditions of Faisalabad city. The mean of five Portulaca cultivars for the 8 morphological traits has been analyzed and given in (Table 2). Analysis of means revealed the significant differences among the Portulaca genotypes for most of the morphological traits.

Table 2. Table of mean values of morphological parameter

\begin{tabular}{|c|c|c|c|c|c|c|c|c|}
\hline Cultivars & ס̊ & 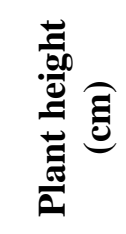 & 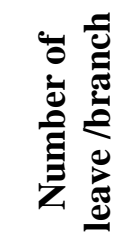 & 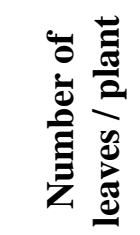 & 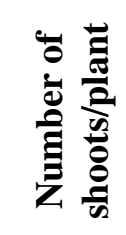 & & 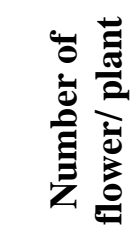 & ప⿱亠凶禸ँ \\
\hline $\begin{array}{c}\text { Portulaca long time } \\
\text { blooming }\end{array}$ & $95.00 \mathrm{a}$ & $13.60 \mathrm{~b}$ & $28.18 \mathrm{a}$ & $427.00 \mathrm{a}$ & $13.13 \mathrm{a}$ & $1.45 \mathrm{a}$ & $28.00 \mathrm{a}$ & $12.93 \mathrm{~b}$ \\
\hline $\begin{array}{l}\text { Portulaca F-1 } \\
\text { Sundial peach }\end{array}$ & $88.33 b$ & $15.42 b$ & $25.20 \mathrm{c}$ & $338.44 b$ & $13.52 \mathrm{a}$ & $1.52 \mathrm{a}$ & $16.67 b$ & $12.93 \mathrm{~b}$ \\
\hline $\begin{array}{c}\text { Portulaca extra } \\
\text { double large } \\
\text { flowered }\end{array}$ & $81.67 \mathrm{c}$ & $19.55 \mathrm{a}$ & $29.17 \mathrm{a}$ & $305.00 \mathrm{~b}$ & $12.81 \mathrm{a}$ & $1.45 \mathrm{a}$ & $24.67 \mathrm{ab}$ & $14.10 \mathrm{a}$ \\
\hline $\begin{array}{l}\text { Portulaca Sunnyboy } \\
\text { Flame, }\end{array}$ & $78.67 \mathrm{c}$ & $15.00 \mathrm{~b}$ & $28.34 \mathrm{a}$ & $356.33 b$ & $9.89 b$ & $1.57 \mathrm{a}$ & $26.67 \mathrm{a}$ & $12.87 \mathrm{~b}$ \\
\hline Portulaca Yubi Pink, & $93.33 a$ & $8.92 \mathrm{a}$ & $25.19 \mathrm{c}$ & $433.00 \mathrm{a}$ & $12.25 \mathrm{a}$ & $1.55 \mathrm{a}$ & $27.67 \mathrm{a}$ & $12.71 \mathrm{~b}$ \\
\hline
\end{tabular}

\section{Germination \%age}

The mean values presented in (Fig.1) revealed that there was a significant difference among the cultivars regarding germination percentage. "Portulaca long time bloom" showed significant difference as compared with genotype "Portulaca extra double large flowered", "Portulaca F-1 Sundial peach" and "Portulaca Sunnyboy Flame". The cultivars "Portulaca long time blooming" showed highest germination i.e. (95\%) and least germination (78\%) was obtained by genotype "Portulaca Sunny boy Flame".

This variation in results may be due to the fact that seed germination of different genotypes is exaggerated by the environmental conditions existing in the surroundings and genotype of Portulaca. This trait is dependent of enormous climatic prevailing conditions such as temperature, light, media, and moisture contents. It is accepted theory that certain species of seed have different responses to temperature according to variety and location. These responses are adaptive success or failure and this is also reasonable to believe [7]. Portulaca seeds that germinated in sporadic temperatures varied from $24-14{ }^{\circ} \mathrm{C}$ to $34-24$ ${ }^{\circ} \mathrm{C}$, representing that Portulaca species might germinate throughout the annum on less high elevation in the area of tropics. Light, though, seems to be supplementary significant for germination than temperature as merely a minute percentage of seeds germinated in shadows or darkness at a few warmth between $14-24{ }^{\circ} \mathrm{C}$ and $24-34{ }^{\circ} \mathrm{C}$, whereas in light, numerous seeds germinated irrespective of the given temperature. A similar retort for $P$. oleracea was descripted from [8].

\section{Plant height (cm)}

The means presented in (Fig. 2) exhibit that there was a significant difference among the 
cultivars with respect to plant height. The genotype "Portulaca extra double largeflowered" gained significantly more average plant height $(19.78 \mathrm{~cm})$ than other cultivars followed by genotype "Portulaca F-1 Sundial peach" that was $(15.25 \mathrm{~cm})$ and least average plant height $(8.84 \mathrm{~cm})$ was observed in genotype "Portulaca Yubi Pink".

Enhancement in plant tallness is the main evident sign of plant growth that is in a straight line affected by hereditary makeup of cultivar and agro-climatic conditions. The difference in the plant heights among different cultivars of Zinnia elegans was also reported by $[5,22]$ give a statement that manifold genes influence the plant height in the Zinnia elegans species. . She divided in her exertion the classified $Z$. violacea plants into six categories typical, $\mathrm{dw} 1$ to $\mathrm{dw} 5$ typical plants were the tallest and $40 \mathrm{~cm}$ in height, trailed by $\mathrm{dw} 130-40 \mathrm{~cm}$. [9] Reported variation in leaf production per plant. [10] Accomplished the gerbera-grown underneath the naturally ventilated green house, which result in maximum produced plant height, plant canopy, spread and number of leaves.

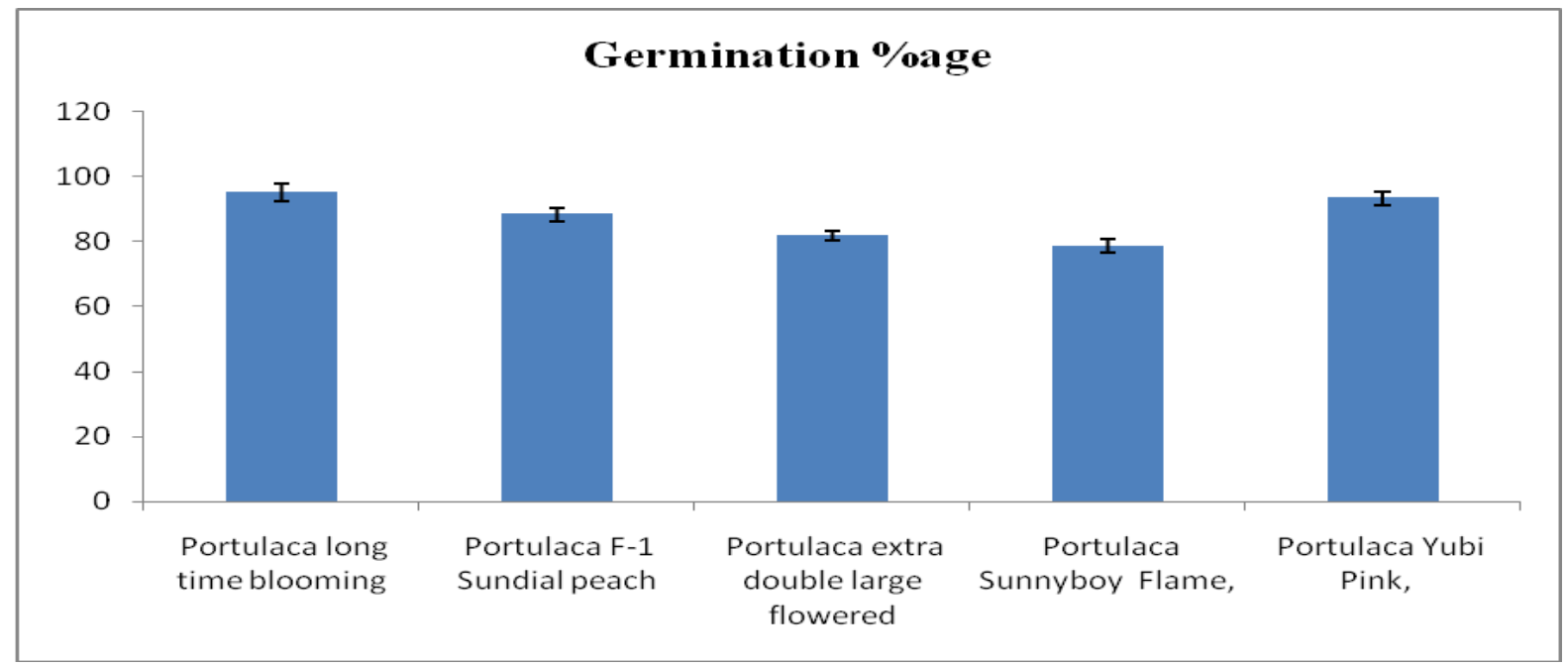

Figure 1. Germination \%age

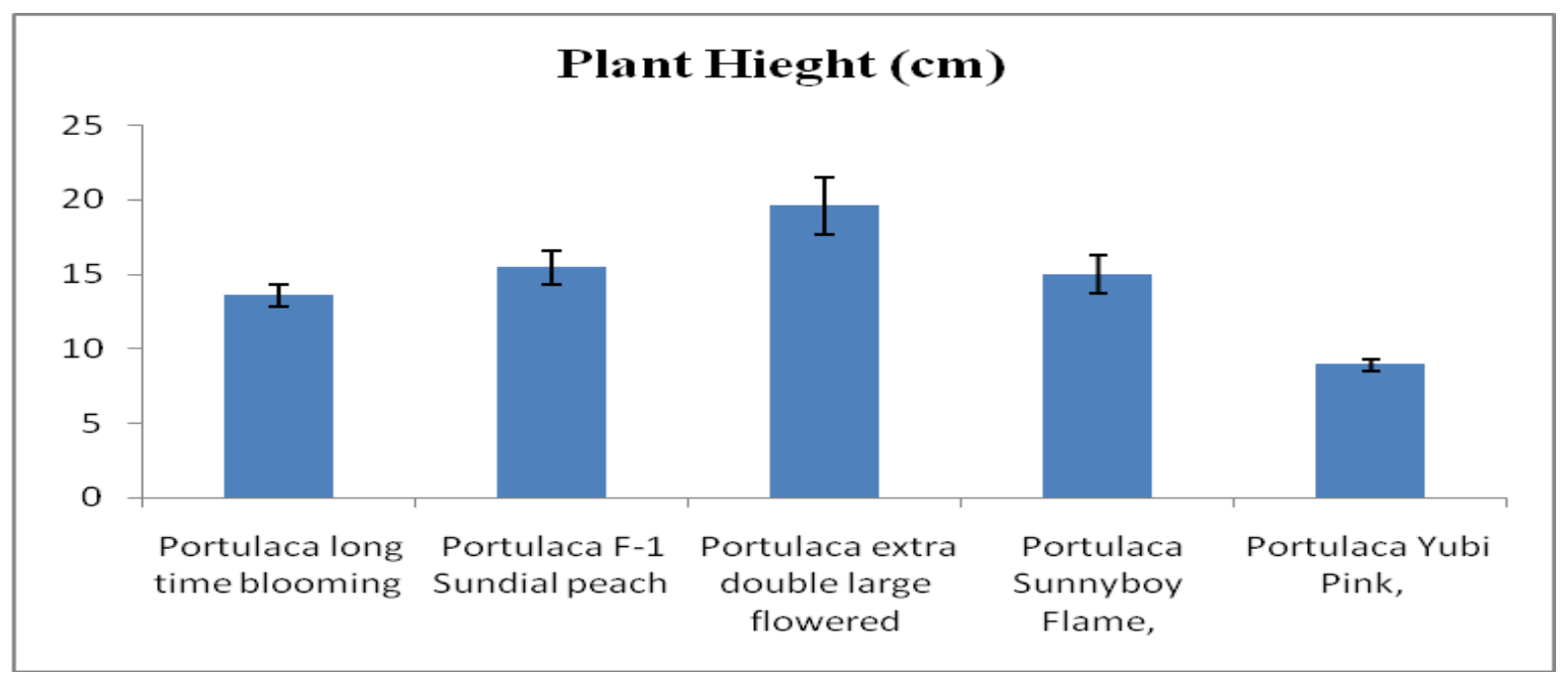

Figure 1. Plant height (cm) 


\section{Number of leaves per branch}

The mean values given in (Fig. 3) revealed that there was a significant difference among the cultivars regarding number of leaves per branch. The genotype "Portulaca extra double large-flowered" with more number of leaves per plant (29) showed significant difference with genotype "Portulaca F-1 Sundial peach" and "Portulaca Yubi Pink". The fewest number of leaves on plant (25) was observed in genotype "Portulaca F-1 Sundial peach".

Production of leaves of any species settled the spread and texture of the plant. They are also called the food factory of plant. Leaves are the principally significant functional units of photosynthesis that greatly influence the escalation of growth and flower yield. Deviation in leaf manufacture per plant has been also elaborated by $[10,11]$ in gerbera. Our results were also evident by [13]. He premeditated the vegetative characters of 9 Gerbera varieties at the time of 1 year age of crop growth under naturally ventilated lath house.

\section{Number of leaves per plant}

The mean values obtained in (Fig. 4) interpret that there were considerable differences amongst the portulaca cultivars about leaves numbers per plant. It is evident from the results that genotype "Portulaca Yubi Pink" significantly produce more number of leaves per plant (430) than other cultivars "Portulaca sunny boy Flame", "Portulaca F-1 Sundial peach" and Portulaca extra double large-flowered. The minimum number of leaves (292) was found in genotype "Portulaca extra double large flowered".

Variation in leaf production per plant could be due to the fact that under given environmental conditions, a cultivar with different genetic makeup performs differently. This was also reported by [10, 11, 13]. They calculated the foliage traits in gerbera elaborated that the utmost plant vigor in Versace while Khaiser resulted in least amount of plant spread. The highest leaves numbers on plant were formed by AVP.07 after that number came of Versace while Yellow Queen generated minimum leaves numbers.

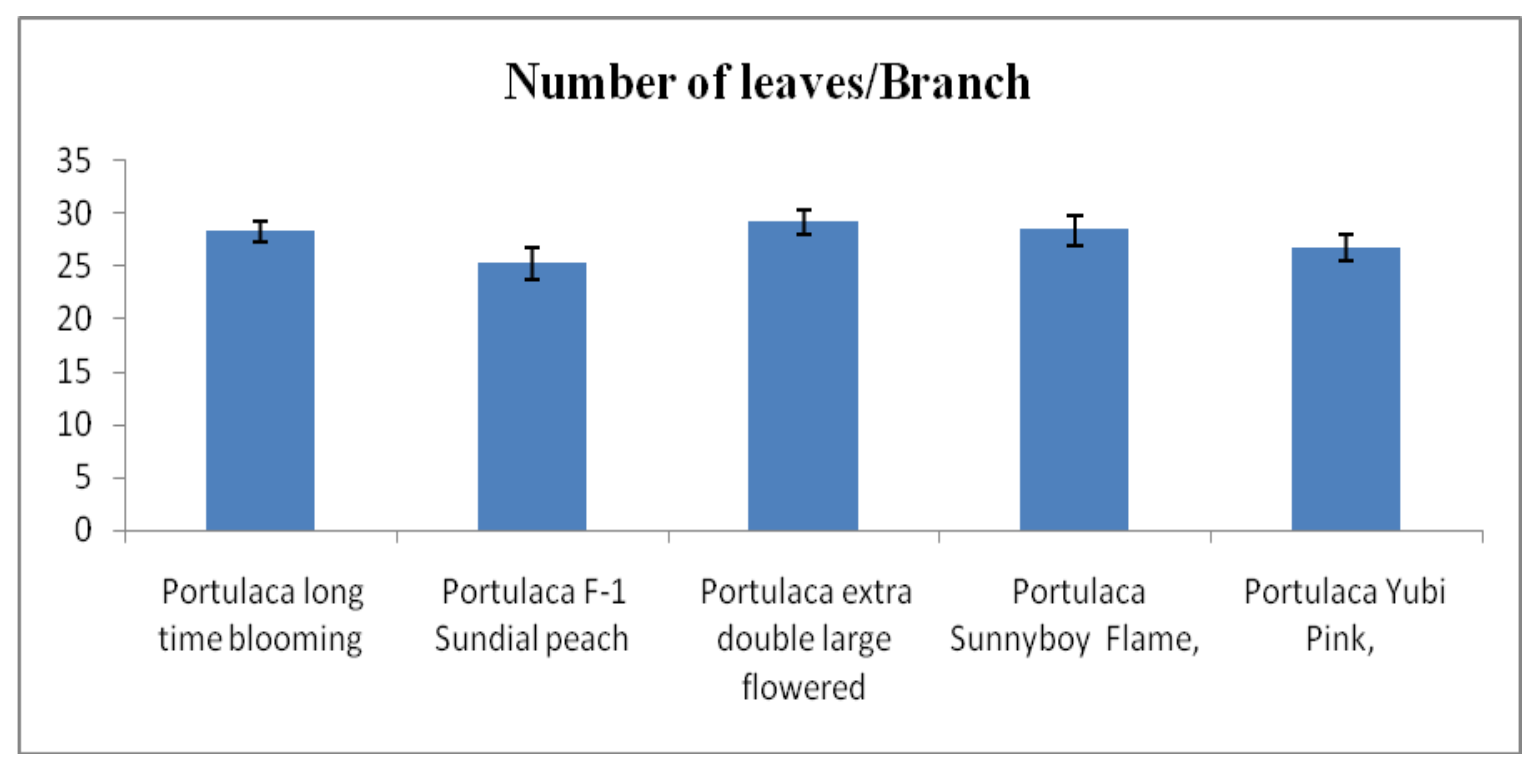

Figure 2. Number of leaves per branch 


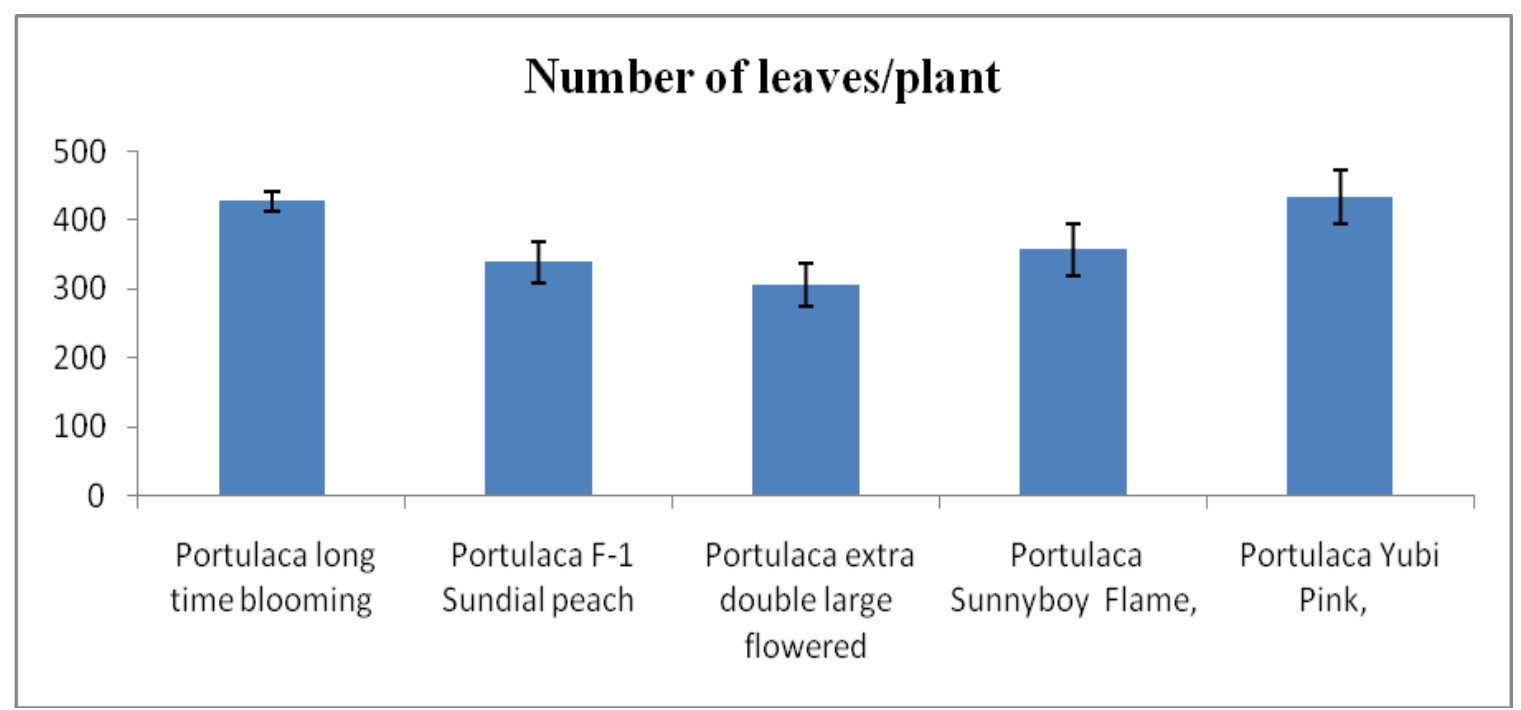

Figure 4. Number of leaves per plant

\section{Number of shoots per plant}

The skeletal structure and shape of the plant is intricate by the branches. They were influenced by high significance by means of the changeable environmental conditions and genetic makeup of cultivars. The mean values given in Fig. 5 exhibit that there was a significant difference among the cultivars regarding number of shoots per plant. As shown in (Fig. 5), the significant difference was found in genotype" Portulaca long time blooming" that produce maximum average number of shoots as compared with minimum average number of shoots (10) producing genotype "Portulaca Sunnyboy Flame".

Our findings were being strengthened by the result of [14] who deliberated the morphological and floral characteristics of annual Zinnia cv. Dahlia giant produced flower beneath natural agro-climatic conditions of city Faisalabad. He found the largest vegetative growth pace, lateral branches number for each plant, lateral branches size, and leaf area. Likewise, study was taken by [15] who noted that height of plant, leaves number for each plant, side branches number, days taken to first flower appearance and flowers number per plant were exaggerated significantly when plants were cultured in manure of leaf mix. It has been reported by [16] that the plants grown in comparatively different environment produced differently leaves and branches on top of the prime axis. The occurrence of escalating number of leaf on shoots in more hot soil tended plants to initial spread for getting settled by absorbing and receiving plenty of light and carbon dioxide.

\section{Leaf length $(\mathbf{c m})$}

The mean values elaborated in (Fig. 6) revealed no significant difference among the cultivars regarding leaf length. Graph shown in Fig. 6 revealed that "Portulaca Yubi Pink" genotype produced leaves with more average leaf length $(1.57 \mathrm{~cm})$ followed by Portulaca long-time blooming gained leaf length of about $(1.548 \mathrm{~cm})$. Average smallest leaves were produced by genotype "Portulaca F-1 Sundial peach" i.e. $1.446 \mathrm{~cm}$ in length.

The shape and size of leaves is an example of conciliation between leaf energy exchange, leaf temperature, respiration, transpiration and photosynthesis. The utmost amplification in nutrient absorption and 
reason to this factor, more photosynthesis might have resulted in more chlorophyll formation with a greater than before leaf size by [17] Findings are in step with [5] who observed small variation in leaf area of different cultivars of Zinnia elegans under natural agro-climate conditions of Faisalabad.

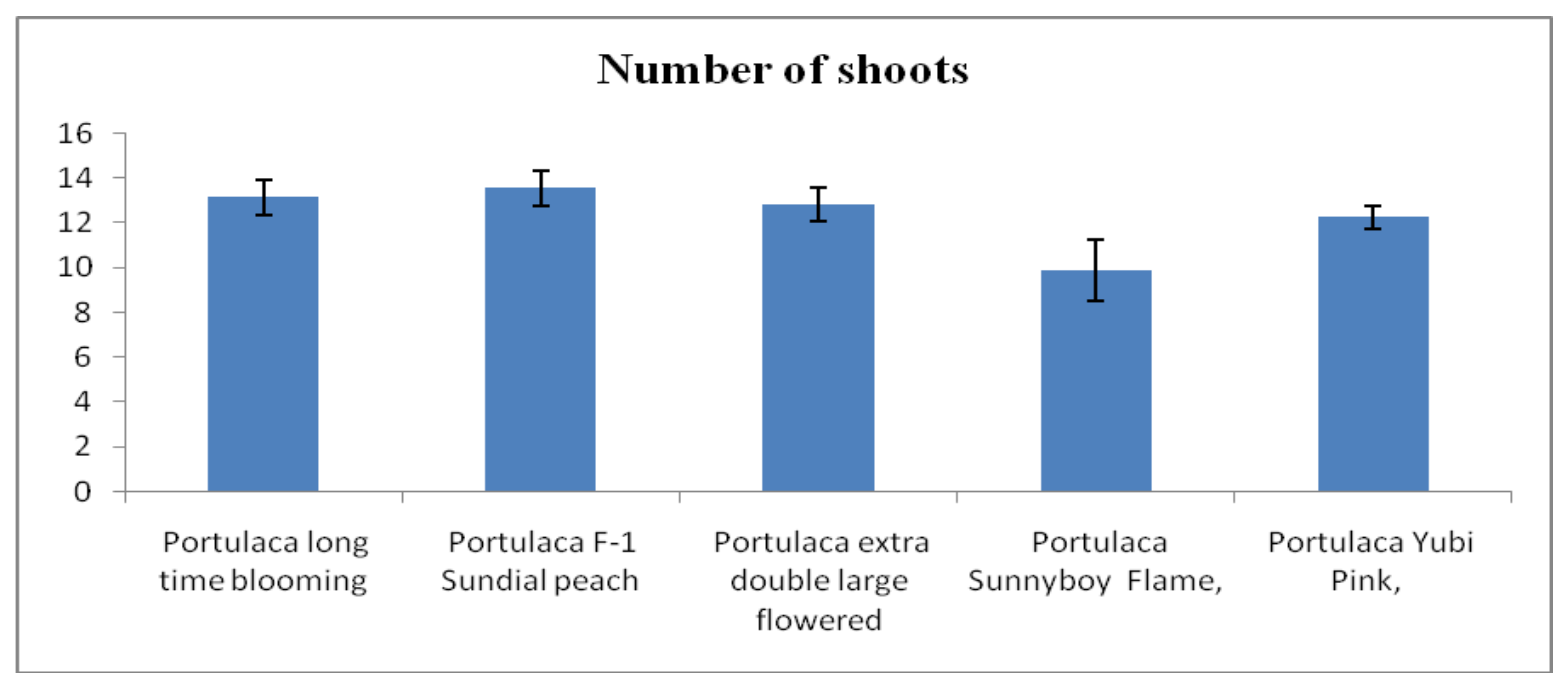

Figure 5. Number of shoots per plant

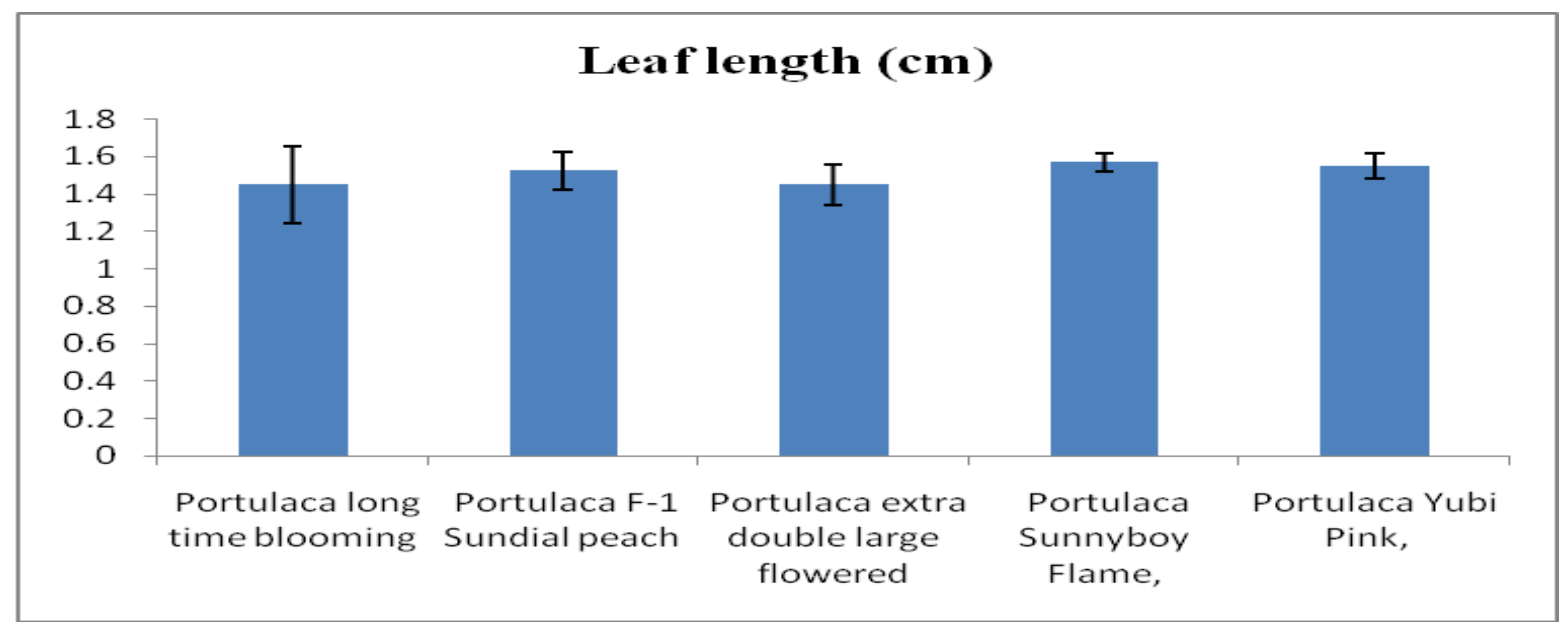

Figure 6. Leaf length $(\mathrm{cm})$

\section{The number of flowers per plant}

The mean values given in (Fig. 7) exhibit a significant difference amongst portulaca cultivars regarding the number of flowers per plant. The data showed significant variation between the genotype "Portulaca long time blooming" and "Portulaca F-1 Sundial peach" and more number of flower (28) was recorded in genotype "Portulaca long time blooming" whereas least number of flower were found in genotype "Portulaca F-1 Sundial peach" that produced 16.66 flowers. No significant difference was found in the mean values of other cultivars regarding the number of flower per plant.

Yield of flowering by Portulaca is moreover an imperative attributing trait toward landscape and floriculture. Our outcomes are in corresponding with [18] that calculated that executed performance of every gerbera genotype diverse with regard to flowers 
numbers each plant, length of the stalk and diameter of flower because of several factors similar to genetic makeup, climatic factors, prevailing growing conditions, land and inputs. Our findings are in line with [19] he gained the maximum Zinnia number of flowers from $20 \times 20 \mathrm{~cm}$ line spacing subsequent to 3 years experiment. [20] Assessed performance of twenty gerbera varieties of solitary, twofold and semi double for its yield and excellence. The maximum flower production noted in cultivar 'Jayce' and the lowest in Cv. Sujan. [5] Studied eleven cultivars of Zinnia elegance showed similar result regarding number of flower per plant. He observed that Zinnia double supper yoga 3F1 Mixed produced averagely 10 flowers and was at top position regarding the number of flowers.

\section{Flower Diameter $(\mathrm{cm})$}

Flower size is a very important trait of seasonal plants in a landscape perspective. The mean values presented in (Fig. 8) revealed that there was significant difference among the cultivars regarding flower diameter. In Fig. 8 it was obvious that "Portulaca extra double large flower" showed significant difference regarding flowers diameter and produce a flower of size $(14.103 \mathrm{~cm})$ and showed significant variation to the other cultivars of followed by "Portulca long time bloom" and "Portulaca Yubi Pink". The least size flowers were recorded in Portulaca Sunnyboy Flame.

Our results were parallel with [5] who observed that flower size greatly varies with respect to subjected environment and type of cultivars. He found that among the eleven cultivars of Zinnia, maximum flower diameter was shown by Zinnia elegans twofold giant dahlia flower followed by Zinnia dreamland F1 hybrid and lowest flower size was exhibited by Zinnia giant new lime. [18] Who observed that the execution performance of every gerbera cultivar changed with esteem to flowers numbers each plant, length of stalk and diameter of flower because of more than a few factors like genetic makeup, climatic factors, prevailing culturing conditions, and land in addition to inputs [21] denoted difference in eminence traits such as diameter of flower, diameter of stem and vase life of solitary, semi twofold and twofold cultivars. [12] evaluate 9 gerbera cultivars for production and eminence of cut flower along with they concluded that by means of quality respect of flowers, the largest flower diameter was noted in Sunset, flower length, length of the stalk in Twiggy while the smallest in Whit Sun.

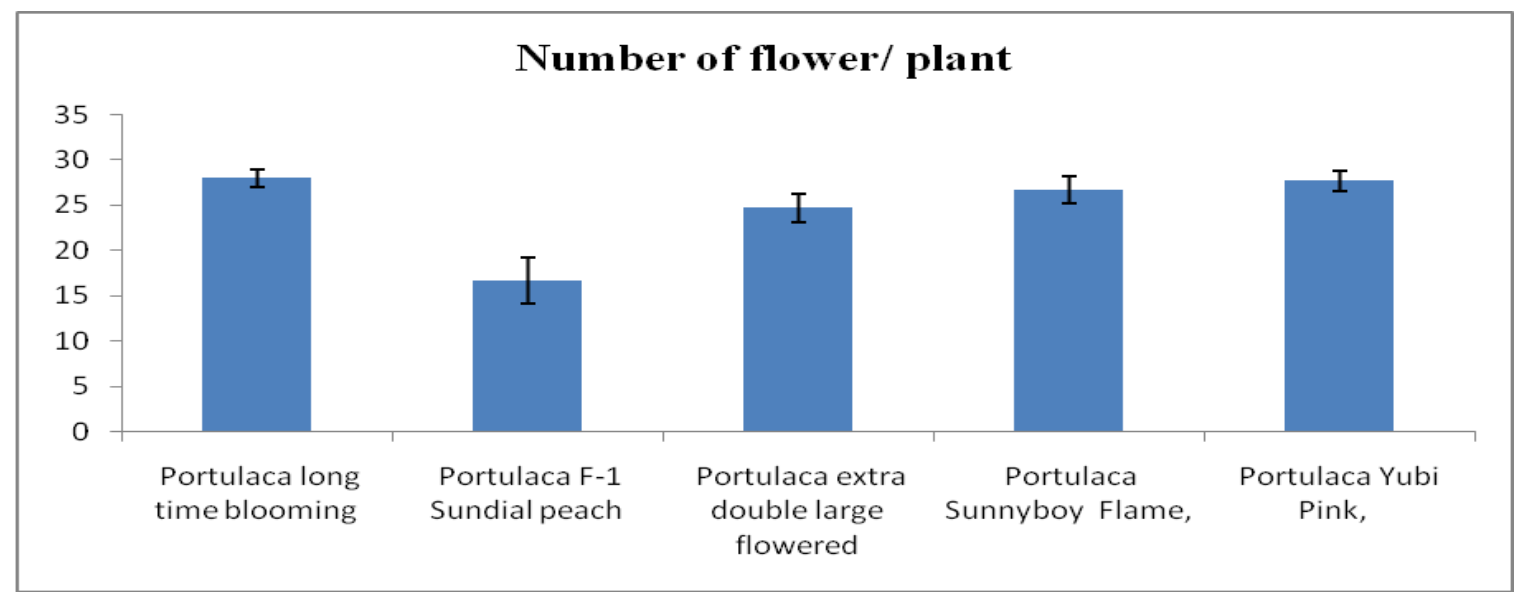

Figure 7. The number of flowers per plant 


\section{Flower diameter (cm)}

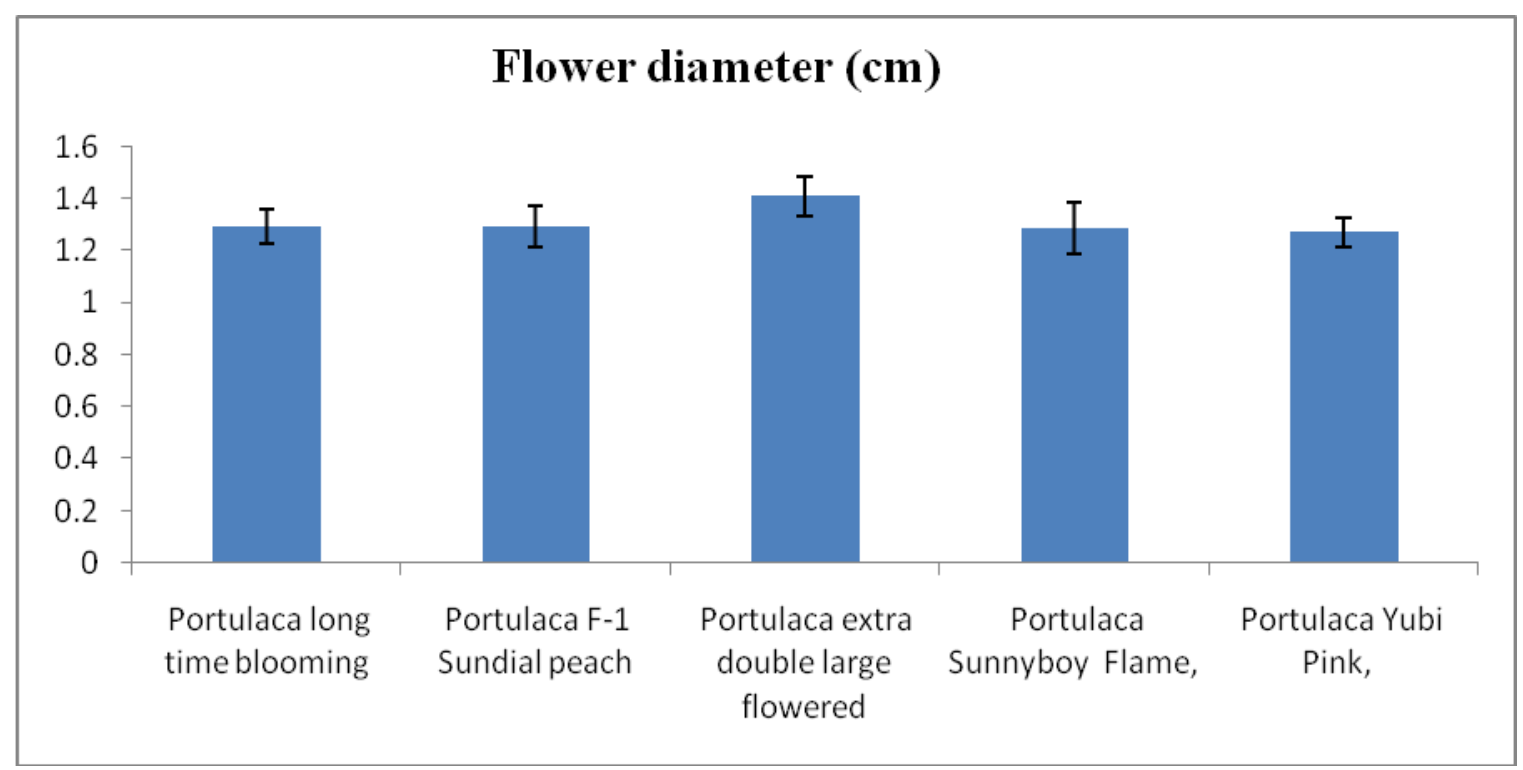

\section{Figure 8. Flower diameter (cm)}

\section{Conclusion}

Morphological traits regarding growth and flowering were assessed by means of appropriate statistical analysis. The trial findings revealed that a substantial significant deviation was found in different yield and quality parameters amongst the five genotypes studied. The Extraordinary performance was demonstrated by genotype "Portulca long time bloom" followed by "Portulaca Yubi Pink" regarding Plant height $(\mathrm{cm})$, shoot number, shoot length, leave numbers on each branch, number of leaves on each plant, days to $1^{\text {st }}$ flower emergence and size of flowers $(\mathrm{cm})$ in natural agro-climatic conditions of Faisalabad, Pakistan.

\section{Authors' contributions}

Conceived and designed the experiment: MFK Pasha, Performed experiment: MFK Pasha, Analyzed Data. MFK Pasha \& A Ahmed, Contribute to material and analysis tools: MFK Pasha \& S Ali, Wrote the paper: MFK Pasha.

\section{Acknowledgments}

The authors would like to thank all the affiliated institutions' learned colleagues for their selfless expert input and technical facilitation.

\section{References}

1. Kazuo I \& Suto K (2002). Role of ethylene in acceleration of flower senescence by filament wounding in Portulaca hybrid. Physiol Plant 104: 603-607

2. Liu L, Howe $P$, Zhou $Y F, X u ~ Z Q$, Hocart C \& Zhang R (2000). Fatty acids and carotene in Australian purslane (Portulaca oleracaea) varieties. $J$ Chromatogr A 893: 207-213.

3. Aronson J \& Halophyte (1989). A Database of Salt Tolerance. Plants of the World. Office of Arid Land Studies, University of Arizona Tucson, AZ.

4. Grieve CM \& Suarez DL (1997). Purslane (Portulaca oleracea L.): a halophytic crop for drainage water reuses systems. Plant Soil 192: 277283.

5. Pasha MFK, Ahmad HM, Qasim M \& Javed I (2015). Performance evaluation of zinnia cultivars for morphological traits under the Agro-climatic 
conditions of Faisalabad. Euro $J$ Biotech Biosci 3(1): 35-38.

6. Steel RCD \& Torries JH (1980). Principle and procedure of statistics. McGraw Hill Book.Co, inc. Newyark 336-354.

7. Negi A, Chauhan K, Shashi \& Todaria NP (1995). Effect of temperature on germination pattern of some trees of Garhwal Himalaya. J of Tree Sci 14: 1113.

8. Singh KP (1973). Effect of temperature and light on seed germination of two ecotypes of Portulaca oleracea L. New Phytologist 72: 289-295.

9. Gupta YC, Dein Lequec Dhiman SR \& Jain R (2004). Standardization of growing media under protected environment for gerbera in mid hill of Himachal Pradesh. J ornam Hortic 7: 99-102.

10. Kandpal K, Santosh Shrivastava R \& Ramchandra N (2003). Evaluation of gerbera (Gerbera jamesonii) cultivars under tarai condition. J Orna Hort 6: 252-255.

11. Kannan M \& Ramdas S (1990). Variability and heritability studies in gerbera (Gerbera jamesonii). Prog Hort 22: 72-76.

12. Singh KP \& Ramachandran N (2002). Comparison of greenhouses having natural ventilation and fan and pad evaporative cooling systems for gerbera production. J Orna Hort 5(2): 15-19.

13. Nair A, Sujatha \& Medhi RP (2002). Performance of gerbera cultivars in the Bay Islands. Indian J of Hort 59: 322225.

14. Ahmad IT, Ahmad MS, Zafar \& Nadeem A (2007). Response of an elite cultivar of zinnia (zinnia elegans cv. giant dahlia flowered) to varying levels of nitrogenous fertilizer. Sarhad J Agric 23: 309-312.

15. Riaz A, Arshad M, Younis A, Raza A \& Hameed M (2008). Effects of different growing media on growth and flowering of zinnia elegans cv. Blue point. Pak $J$ Bot 40: 1579-1585.

16. Awal MA \& Ikeda T (2002). Effects of changes in soil temperature on seedling emergence and phonological development in field-grown stands of peanut (Arachis hypogaea). Environ Exp Bot 47: 101-113.

17. Belorkar PV, Patel BN, Golliwar VJ \& Kothare AJ (1992). Effect of nitrogen and spacing on growth, flowering and yield of African marigold. $J$ Soils and Crops 2: 62-4.19.

18. Horn W, Wricke G \& Weber WE (1974). Genotypic and environmental effects on characters expression in Gerbera jamesonii. Gareten Bauwissenssenschaft 39: 289-300.

19. Oberthoya K (1981). Methods of growing Zinnia Trnaplants and their effect on seed yields. Acta Phytotechnica 37: 55-70.

20. Loser H (1986). Gerbera cultivars; help with the enormous range available. $G b+G W$ 86: 836-841.

21. Garibaldi E A \& Deambrogio F (1988). Extending the life of cut flowers of Marguerite Informatory. Agrario 44: 97-104.

22. Lien AL (1968). Inheritance in Zinnia elegans, M.S. thesis, Colorado State University, Fort Collins, Colorado, USA. Flower Breeding and Genetics 337-357. 